ISSN 2745-7168 (DARING)

MUQODDIMA Jurnal Pemikiran dan Riset Sosiologi 2 (1), 2021: 37-46

ARTIKEL

DOI: $10.47776 /$ MJPRS.002.01.03

\title{
Contested Gender Roles and Relations in Matriarchal Minangkabau
}

\section{Perebutan Peran dan Hubungan Gender dalam Sistem Matriarkal Masyarakat Minangkabau}

\author{
Ahmad Hakam \\ Program Studi Pendidikan Agama Islam, Fakultas Ilmu Sosial, \\ Universitas Negeri Jakarta \\ E-mail: ahmad-hakam@unj.ac.id
}

\begin{abstract}
This study aims to explore the gender roles and relations in the Minangkabau society and how the situation is changing due to some interactions with other influential factors, mainly Islamic teaching and nation-state projection. This article argues that although the Minangkabau matriarchal traditions are influenced by particularly the two driving forces, there have been both continuity and change which prove that the gender roles and relations are a highly contested discourse. This study used library research, and miniethnographical approach which involved several field observations and interviews through casual conversation with Minangkabau people. The results show that gender and the conception of women and men are highly contested, especially in the region where more than one influences are competing. Although there is a number of powerful discourse disparities, especially the Islamist movement and the state, the creation and instillation of new definitions and identities of the Minangkabau is reworked within their ideologies of gender and rank, kinship and matriliny.
\end{abstract}

Keywords: Minangkabau, gender role, gender relation, matriarchy, Islam, tradition, adat 


\begin{abstract}
Abstrak
Penelitian ini bertujuan untuk mengeksplorasi peran dan relasi gender dalam masyarakat Minangkabau dan bagaimana situasi berubah akibat interaksi dengan faktor-faktor lain yang berpengaruh, terutama ajaran Islam dan proyeksi negara-bangsa. Artikel ini berargumentasi bahwa meskipun tradisi matriarkat Minangkabau dipengaruhi terutama oleh dua kekuatan pendorong tersebut, terdapat kontinuitas dan perubahan yang membuktikan bahwa peran dan relasi gender merupakan wacana yang sangat diperebutkan. Penelitian ini menggunakan studi kepustakaan, dan pendekatan mini-etnografi yang melibatkan beberapa observasi lapangan dan wawancara melalui percakapan santai dengan orang Minangkabau. Hasil penelitian menunjukkan bahwa gender dan konsepsi perempuan dan laki-laki sangat diperebutkan, terutama di wilayah di mana lebih dari satu pengaruh bersaing. Meskipun ada sejumlah disparitas wacana yang kuat, terutama gerakan Islamis dan negara, penciptaan dan penanaman definisi dan identitas baru Minangkabau dikerjakan ulang dalam ideologi gender dan pangkat, kekerabatan dan matrilinitas mereka.
\end{abstract}

Kata Kunci: Minangkabau, peran gender, hubungan gender, matriarkal, Islam, tradisi, adat

\title{
Introduction
}

In the western part of the Sumatera Island, there is a large ethnic group that features distinctive system of social order in which women have important position. Many acknowledge that Minangkabau society has been matriarchal since long time ago far before Islam arrived in around 16th century. This matriarchate is so rooted in its tradition and custom that there is almost no drastic change in the way people organise their family system in contemporary time. It also becomes a unique ethnic identity that makes it different from the rest of hundreds of other ethnics living in Indonesia. Each ethnic has its adat which is understood as 'a whole body of rules, traditions and beliefs' or 'traditions and customary law' (Schrijvers and Postel-Coster 1977:80). Matrilineal family system is the core of the Minangkabau adat and it affects many aspects of life in family as well as in the whole community or the clan.

The Minangkabau people constitute an ethnic and they populate in one province called West Sumatera or Sumatera Barat. West Sumatera (province) can be used almost interchangeably with Minangkabau (ethnic group) along with its culture. When one speaks culturally about Minangkabau, the first thing come in mind would be most probably its characterised matriarchal system. The women inherit land and property and take full control of the family economy and play crucial role in decision making together with the men. In addition, the conception of women among Minangkabau people is also unique. Women are highly profiled and positioned to the stage where they are seen as 'the dominant symbol of the common good' and more visibly they are even symbolised as the 'central pillar of the traditional house, which is the oldest pillar because it is the first erected'(Sanday 2002:82-23). This firm tradition and custom or adat then go through some intriguing 
dynamics as the socio-political circumstance changes.

This paper will explore the gender roles and relations in the Minangkabau society and how the situation is changing due to some interactions with other influential factors mainly Islamic teaching and nation-state projection. This article argues that that although the Minangkabau matriarchal traditions are influenced by particularly the two driving forces, there have been both continuity and change which prove that the gender roles and relations are a highly contested discourse.

\section{Metode}

This method used in this study is library research and field research through observation and interview. Data were obtained from relevant case studies. Authoritative reports (Blackwood 1995; Sanday 2002) on Minangkabau society become the main reference while at the same time conducting field visit several times to West Sumatera for observation and having conversation with colleagues and in-laws who are from Minangkabau ethnic background. At this stage of qualitiative inquiry, an interpretive, naturalistic approach to the world is used and studied in the subject's natural settings, to understand or to interpret the phenomenon (Ritchie and Lewis 2003:3).

\section{Findings and Analysis}

The data obtained from literature were examined and used as an analysis tool for seeing the phenomenon in Minangkabau society where the contestation about how gender role and relation are perceived take place. The observation and to a great extent confirm the previous research on the society but there are also dynamics that is happening, especially in a more urban and modern Minangkabau community. Nevertheless, it is still obvious that the matriarchy among Minangkabau people is a distinctive traditional element that is celebrated and stable until today. The tradition, throughout history, remain in contestation with other forces such as religion, national interest, and interaction with other cultures.

\section{Women in Minangkabau Tradition}

Minangkabau tradition, in general, according to Schrijvers and Postel-Coster (1977:85), has special and specific attention to women. Having daughters, for example, is very important since they are the children who will inherit family properties, and having no daughters at all means disappointment since the future female figure cannot continue the mother lineage. Likewise, it is noticeable when girls reach about seven years of age; they already behave like little mothers. They have a number of duties regarding household and taking care of younger siblings (Schrijvers \& Coster 1977:94). When they are adult and married, their power is extended to economy and social realms. This privilege includes a control over land inheritance and hosting their husbands. In the society, men are exchanged between families at marriage. The wife will collect her husband from his household and, with her female relatives, bring him back to her household to live. When a couple divorce, the husband will collect his belongings and leave (Kosty 2002). 
Schrijvers and Postel-Coster (1977:94) also point out that when a woman reaches motherhood, she will be honoured since she is fulfilling the valued tasks. 'Her status implies rights on the family property and the usufructs of it, rights of decision in household and home affairs, and the actual responsibility for the upbringing of children'. In addition, when women reach their middle age, they will be more prominent in the house and the family while the men are supposed to be able to make public speeches and take responsibility in the village leadership. This relationship is even reflected neatly in traditional house of Minangkabau people. The special room in the back and the kitchen is for the women and the men's part is the big front veranda where guess is welcome and meeting is held. In this setting 'women are associated with the small circle of the family, the village ground, with continuity and traditional wisdom' while men are linked 'with public life, politics, change and individual performance'(Schrijvers \& Coster 1977:85). It is also confirmed by the local people that women have more power in the matters of disbursement and use of ancestral property, while men have more responsibilities in the 'government' (Sanday 1990:144).

This, however, according to Sanday (1990:145), should not be understood in the face value. She points out that the centre power is actually in the house where men are obliged to first discuss the matters with the women and with matrilinear male and female relatives before going to make decision and consensus in the village office or village council house. This system has high degree of respect since it is codified in Minangkabau ethnic tradition or adat and it holds that 'males and females may have different rights, but since both are necessary to perpetuate adat the two are at the same level' (Sanday 1990).

Such type of relation has existed for centuries and the idea of adat is very influential and respected, if not sacred. This ancestrally linked tradition regulates and legitimises traditional, political and ceremonial life in the villages (Sanday 1990:146). After Islam arrived and become the religion of the Minangkabau society since more than four centuries ago, the Minangkabau is well-known for their adherence to Islam. This does not mean there is no friction between the Islamic teaching and their adat. Schrijvers and Postel-Coster (1977:86) believe that in some ways the Minangkabau adat and Islamic values are compatible (or regarded as compatible), and in other ways, however, the two are contrary. Yet, that there is no 'full' assimilation between the two does not necessarily mean a conflict. They can still coexist (Schrijvers \& Coster 1977). The Islam and Minangkabau adat 'incompatibility' become a serious hostility when the Islamic reform movements, mainly the fundamentalists, which is originated in the Middle East, reached West Sumatra.

\section{Between Adat and the New Islamic Modernist Movement}

There are other modernist movements as well that call for rationalism and individualism which in a way contradict the collectivism of the adat nature. There are examples of matters differently perceived by Minangkabau ethnic tradition and Islam. Man, for example, according to Islam, is responsible to his God and 
not necessarily to the community in a ritualistic way as in the Minangkabau adat. Similarly, individual property can be recognised in Islam while in the Minangkabau tradition communal matriarchal property is more emphasised (Schrijvers \& Coster 1977). Islamic teaching also demonstrates its preference to patriarchal family system where men or father is the household head. Other issues such as divorce appear to be contrary. According to their interpretation of Islam, it is the exclusive right of men, while women still can request, but the pronunciation should come from male side. More obviously the allocation of inheritance rights in Islam is favouring men, if this is to be literally applied, while in the Minangkabau system women are the sole holder of inheritance, men have no right.

However, Islam and its teachings now have been a good companion and part of the West Sumatra people who in general see no conflict between their adat and Islam. Although conflicts happened in the past (Dobbin 1983; Whalley 1993 in Blackwood 1995:127), 'the two have come to be mutually constructed' (Blackwood 1995). In an interview conducted by an anthropologist, one of the senior male leader or penghulu, Idrus Hakimy (Dt. Rajo Penghulu) stated that there is no contradiction between matrilineal adat and Islam. In another occasion he also emphasized that they go together. 'In adat the possessions go to women. In Islam possessions go to men and women. But actually, the two things are not contradictory.' He further adds that in Minangkabau tradition there are clan and individual possessions; the first goes to women and the second is shared between women and men. This is also actually not contradictory with the Qur'an tenets that say that women are also important and respected in the family. The matrilineal system which gives special right to women, therefore, is in accordance with that (Sanday 1990:127). Islam and Minangkabau adat accommodate each other and even they 'are accepted as equally sacred and inviolate, handed down from the godhead' (Sanday 2002; Kosty 2002). And nowadays 'at a time when consumerism is more prevalent in Indonesia than ever before, these sacred principles of Minangkabau culture and society act to support one another' (Sanday 1990). It may be inferred that Islam and Minangkabau adat now become two 'official' cultures of the West Sumatran people.

\section{Between Adat and the National Interest}

Meanwhile, beside the adat and Islam encounter, the contestation on gender roles and relations in Minangkabau has another player, mainly after the new nation state is formed and stable enough to run its projects. The emergence of nation state has changed the socio-cultural environment of its members. The Minangkabau, as part of Indonesia, inevitably has exposure to the larger power that influences some of the system. This phenomenon can be understood in the relation between state and society in the notion of citizenship and its right and responsibility. Quoting T.H. Marshall's definition (1950; 1975; 1981), Yuval-Davis (1997:21-22) states that citizenship as 'full membership in the community' encompasses civil, political, and social rights and responsibilities. She then comes with the concept of citizenship which 'is perceived to be multi-layered and often diverse, relating to local, ethnic, 
state and often trans-state communities.'

The Minangkabau can also be best analyzed in this framework especially during the intensive nationalism program by the New Order regime which ruled for thirty-two years, from 1966 until 1998. As members of nation and as citizens, women's role and expectation are often define and redefined by state. Therefore, women's citizenship 'is usually of a dual nature: on the one hand they are included in the general body of citizens; on the other hand, there are always rules, regulations and policies which are specific to them (Yuval-Davis 1997:21-22). The notion of women in Minangkabau has been characterised by this phenomenon. On the one hand they are regulated based on the local traditions and on the other there are other influences that consequently contest the establishment. One contestation is on the conception of women in Minangkabau by the people and the government.

According to Sullivan (1983:148 in Blackwood 1995:135), Indonesian state's policies impose the roles of wives and mothers as a support for husband and family and this is also important to state development. The programmes created by the state also reflect this vision. There are in general five major duties of women: 'to be a loyal supporter to her husband; to be caretaker of the household; to produce future generations; to raise her children properly; and to be a good citizen'(Ibid.). This national project is enforced through regional programmes and women activities managed by province and district authorities. The PKK (Family Welfare Organisation), for instance, have played significant role in constructing their view on themselves. Blackwood asserts that PKK 'is a voluntary organization and is the main channel used by the state to reach women at the grass-roots level' (Royal Netherlands Embassy 1987 in Blackwood 1995:135). It contains socialcultural programs required by the state. It holds a variety of events such as cooking contests and cosmetics classes and involvement in ceremonial affairs. Since it is locally administered, the state-sponsored organization can extend its participation to the domestic policies with the state support. It thus creates 'new practices that incorporate both state directives and adat' (Blackwood 1995:145-146). Since the PKK managed to blend 'between domestic and kinship affairs', the meaning of Minangkabau womanhood changes into other directions; it is no longer solely based on the conception given by the ethnic tradition (Blackwood 1995:146).

Beside the state secular view's influence on the notion of womanhood, there is religious basis as well which influences the policy. With Islam as one of the official religions in Indonesia and its largest followers, the state policies are to some extent also influenced by its teachings. Some discourse that the state and Islam have in common is the assertion that the primary duty of women is to be good wives and mothers. 'Man is suited to face the hard struggles of life on account of his stronger physique' and 'woman is suited to bring up the children because of the preponderance of the quality of love in her' (Blackwood 1995:20). Although this does not sound aggressive, Blackwood said, it reinforces the state view that women should have domestic life taking care of husband and family and it indirectly portray the image of men as the breadwinner and active outside (Blackwood 1995). 
In addition, the Indonesian Marriage Law of 1974 also shares the idea with Islam that 'the husband is the head of the family and the wife is the mother of the household' (Salyo 1985 in Blackwood, 1995:20). Yet, as discussed before this does not significantly affect the family gender roles in Minangkabau society since it has been reconciled by the Minangkabau officials themselves and the people in general celebrate their ethnic tradition as well as their Islam.

The state though has another way. The national projection on the idea of women is performed in a more subtle way through the appropriation of various cultural symbols. There is representation of mother which is highly profiled in Minangkabau custom. It is often called Bundo Kanduang or real mother. It is the representation of Mother, sister, and daughters as centre of family and society. It resembles the goddes's name which portray that women are designated to hold leadership positions, particularly regarding the inheritance that passes through the mother's line (Monaghan 2009:217). This term has been appropriated by the state to educate women about their duties as mothers (Sanday 1995:139).

The state's model mother, ibu teladan or 'ideal mother' award program promoted by the state enforces the idea of successful mother. Mother is awarded if she is successful in children upbringing including provision of the best health, education, and nutrition (Sanday 1995). This is the national project and according to Sanday (1995:140), in the province of West Sumatra women who win this award are called Bundo Kanduang. By this, the concept of Bundo Kanduang has been reduced from lineage elder to only domestic wife. She argues that it is not a woman's leadership or management of her kin group that is rewarded, but fulfilment of certain tasks labelled domestic by the state. Thus, women's vision of themselves as Bundo Kanduang is overwritten by an alternate vision of Bundo Kanduang promulgated by the state' (Sanday 1995).

\section{Contested Gender Roles and Relations}

The range of these discourses ensues some consequences in the way women and men are viewed and in the way they will behave in family and in society. According to Blackwood (1995:151), women in public or in national occasion may need to agree with the national discourse [although it may change recently, especially post-1998 reform], as citizens of the state, that they support their family as a wife, childbearer, and childrearer. They may 'downplay' their extension of their power in their speech in state officials-led meetings or gatherings, but at the same time it is evident that the centrality of women remains essential in the ceremonial and kinship relations. This is seen particularly in the local villages. Blackwood further explains (1995:151):

"Minangkabau women operate within a number of alternative discourses, none of which are exclusive. Their actions cannot be construed as a subversive challenge nor resistance to dominant ideologies because their power is legitimated in village discourse and substantiated by adat. In their efforts to manage their identities in the village, women may emphasize in turn idioms of modernity or religion or adat, or they may play up their rank, wealth or standing within the community. The use of these discourses is highly contextualized and variable, the result of differences in power, 
rank and wealth. Ultimately, the multiplicity of discourses fosters subtle shifts in social identity, gender and power as rural elite women seek new constructions that mediate among alternative ideologies."

The competing ideas on gender roles and relations in West Sumatra create some sorts of dynamics which are responded differently by the society within the community and the wider scope of people and academia. Defining, redefining, negotiation, resistance and acceptance color the contour of the Minangkabau society. The controversial matriarchal family system, confronted with Islamic values and state policies does not exhibit rigid rejection of new ideas coming from outside nor duly assimilate them. This circumstance contributes to richer understanding of gender and the creation of more alternatives and 'multiple interpretations of gender available to women in West Sumatra' (Blackwood 1995:151).

\section{Conclusion}

This study shows that the Minangkabau is still the largest and most stable matriarchal society in the world (Sanday 2002) despite its engagement with several influences that consequently reshape or retain their understanding of women and men roles and relations. It is evident that gender and the conception of women and men are highly contested especially in the region where more than one influences are competing. Although there is a number of powerful discourse disparities, especially the Islamist movement and the state, the creation and instillation of new definitions and identities of the Minangkabau is reworked within their ideologies of gender and rank, kinship and matriliny (Blackwood 1995:151). Thus it is not quite surprising that Minangkabau people are renowned for their staunch with Islam as well as their pride with their matriarchate. 


\section{References}

Blackwood, E. 1995. Senior Women, Model Mothers, and Dutiful Wives: Managing Gender Contradictions in a Minangkabau Village' in Ong, A. and Peletz, M. G. (Eds) Bewitching Women, Pious Men: Gender and Body Politics in Southeast Asia. Berkeley, CA: University of California Press. pp.124-158.

Fahmi, R. \& Prima Aswirna. 2014. The Paradox of Islam and Culture (Tradition and Belief about Gender Perspective in West Sumatera. Buletin Al-Turas 20(2) http://journal.uinjkt.ac.id/index.php/al-turats/article/view/3763

Kosty, P. 2002. Indonesia's Matriarchal Minangkabau offer an alternative social system. EurekAlert! University of Pennsylvania. Available online at http://www. eurekalert.org/pub_releases/2002-05/uop-imm050902.php

Lincoln, D. \& Norman K. Denzin. 2003. Turning Points in Qualitative Research: Tying Knots in a Handkerchief. Walnut Creek: Rowman \& Littlefield Publishers, Inc.

Monaghan, P. 2009. Encyclopedia of Goddesses and Heroines. Mullane Literary Agency: Greenwood.

Sanday, P. R. 1990. Androcentric and Matrifocal Gender Representations in Minangkabau Ideology in Sanday, P. R. and Goodenough (Eds.) Beyond the Second Sex: New Directions in the Anthropology of Gender. Philadelphia: University of Pennsylvania.

Sanday, P. R. 2002. Women at the Center: Life in a Modern Matriarchy. Ithaca, NY; London: Cornel University Press. 
46 | Contested Gender Roles and Relations in Matriarchal Minangkabau

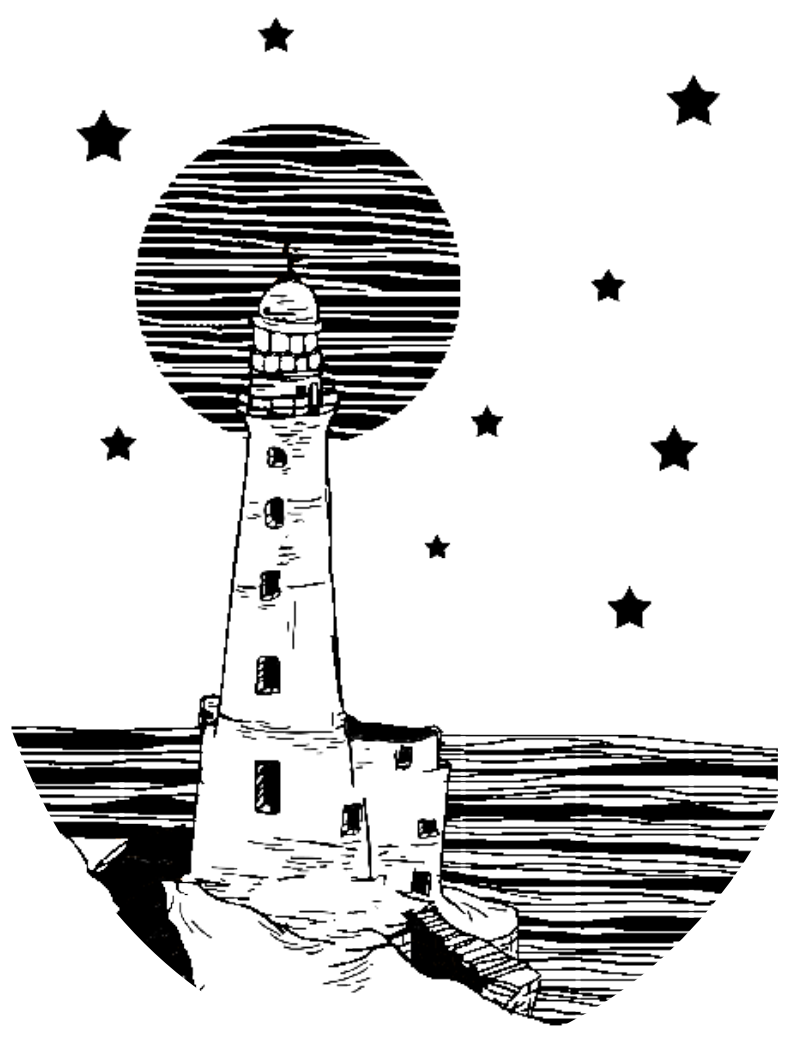

